\title{
Mer aterosklerose med luftforurensning
}

\section{Finpartikulært svevestøv i områder nær motorveier ga økt utvikling av aterosklerose i halsarterien, mens sanering av forurensningen stanset utviklingen av aterosklerose.}

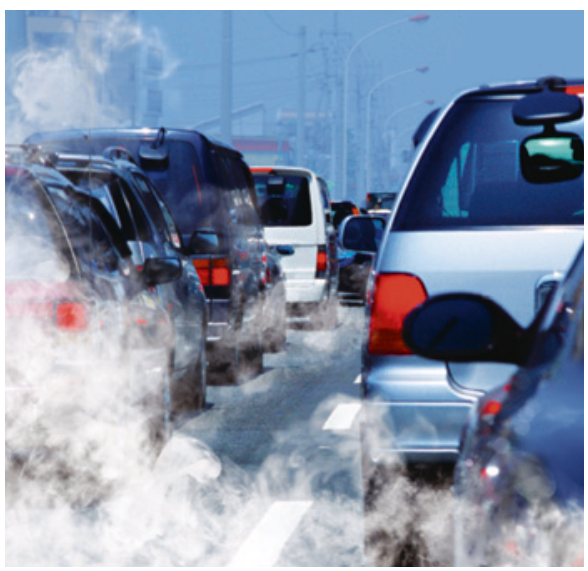

Illustrasjonsfoto Thinkstock
I en studie med over 5300 deltakere fra seks storbyområder i USA ble endringer i tykkelsen av intima/media $i$ a. carotis communis (IMT) målt med ultralyd og brukt som surrogatvariabel for utviklingen av aterosklerose (1). Gjennomsnittlig observasjonstid var 2,5 år, og deltakerne gjennomgikk to ultralydundersøkelser. Det var en assosiasjon mellom tykkelsen av intima/media $\mathrm{i}$ arterien og $\mathrm{PM}_{2.5}$-verdier («particulate matter», med aerodynamisk diameter mindre enn $2,5 \mu \mathrm{m}$ ) i luften i alle områdene. Assosiasjonen var også til stede etter justering for en lang rekke mulig konfunderende faktorer. Der luftforurensningen avtok, avtok også økningen i intima media-tykkelsen.

- Denne prospektive studien er viktig, sier avdelingsdirektør, professor Martinus Løvik ved Folkehelseinstituttet. - Resultatet er ikke uventet og samsvarer med tverrsnittstudier og dyreforsøk. Vi har lenge visst at fine partikler $\left(\mathrm{PM}_{2.5}\right)$ ikke bare affiserer lungene, men også gir en systemisk betennelse med effekt bl.a. på diabetes og arteriosklerose. Mekanismene er ennå ikke helt klarlagt, men aktiverte betennelsesceller kan påvises i blodsirkulasjonen. Inhalasjon av dieseleksospartikler påvirker mikro-RNA som styrer gener som er involvert i betennelsesreaksjoner, sier Løvik.

- Det viktige med denne studien er styrken som ligger i det prospektive designet, doserespons-forholdene og dokumentasjonen av at det nytter å gjøre noe: Reduksjon av luftforurensningen ga redusert arterioskleroseutvikling i løpet av en så kort periode som to og et halvt år. Dette er viktig kunnskap for forebyggende helsearbeid og sender et budskap også til politikerne, sier Løvik.

\section{Haakon B. Benestad}

h.b.benestad@medisin.uio.no

Universitetet i Oslo

\section{Litteratur}

1. Adar SD, Sheppard L, Vedal S et al. Fine particulate air pollution and the progression of carotid intima-medial thickness: a prospective cohort study from the multi-ethnic study of atherosclerosis and air pollution. PLoS Med 2013; 10: e1001430.

\section{Fedmekirurgi ved diabetes type 2}

\section{Gastrisk bypass-operasjon ga bedre blodsukkerkontroll enn intensiv medisinsk behandling alene hos type 2-diabetikere med BMI på $30-40 \mathrm{~kg} / \mathrm{m}^{2}$. Men kirurgi ga også flere alvorlige bivirkninger.}

En amerikansk studie har sett på effekten av gastrisk bypass-kirurgi hos type 2-diabetikere (1). Endepunktet var en kombinasjon av blodsukker-, blodtrykk- og lipidverdier. Deltakere med type 2-diabetes og fedme $\operatorname{grad} 1-2$ (BMI $\left.30-40 \mathrm{~kg} / \mathrm{m}^{2}\right)$ ble randomisert til to grupper, der den ene gruppen $(n=60)$ mottok intensiv medisinsk behandling inkludert livsstilsråd, mens den andre gruppen $(n=60)$ fikk utført gastrisk bypass i tillegg til den medisinske behandlingen. Gruppene ble fulgt i ett år. Totalt 11 deltakere $(19 \%)$ i medisingruppen og 28 (49\%) i kirurgigruppen nådde det kombinerte primære endepunktet $(\mathrm{HbA} 1 \mathrm{c}<7,0 \%$, LDL-kolesterol $<2,6 \mathrm{mmol} / \mathrm{l}$ og systolisk blodtrykk $<130 \mathrm{~mm} \mathrm{Hg}$ ). Medisingruppen hadde et gjennomsnittlig vekttap på 7,9\%, versus $26,1 \%$ i kirurgigruppen. Det ble registrert 15 alvorlige komplikasjoner i medisingruppen og 22 alvorlige komplikasjoner i kirurgigruppen, deriblant fire perioperative og seks postoperative komplikasjoner. Signifikant flere pasienter i kirurgigruppen utviklet mangel på ulike næringsstoffer.
- Dette er den første randomiserte kontrollerte studien der man ser på tilleggseffekten av fedmekirurgi hos diabetespasienter som også behandles medisinsk, sier professor Jøran Hjelmesæth, leder av Senter for sykelig overvekt i Helse Sør-Øst ved Sykehuset i Vestfold. - Uventet få pasienter i kirurgigruppen nådde det primære endepunktet, og den økte risikoen for komplikasjoner maner til ettertanke. Det trengs flere gode studier av lenger varighet som kan belyse balansen mellom klinisk nytte og alvorlige bivirkninger av gastrisk bypass hos type 2-diabetikere med fedme grad 1 før slike operasjoner tilbys rutinemessig.

\section{Hanne Støre Valeur}

hanne.store.valeur@legeforeningen.no

Tidsskriftet

\footnotetext{
Litteratur

1. Ikramuddin S, Korner J, Lee WJ et al. Roux-en-Y gastric bypass vs intensive medical management for the control of type 2 diabetes, hypertension, and hyperlipidemia: the Diabetes Surgery Study randomized clinical trial. JAMA 2013; 309: 2240-9.
}

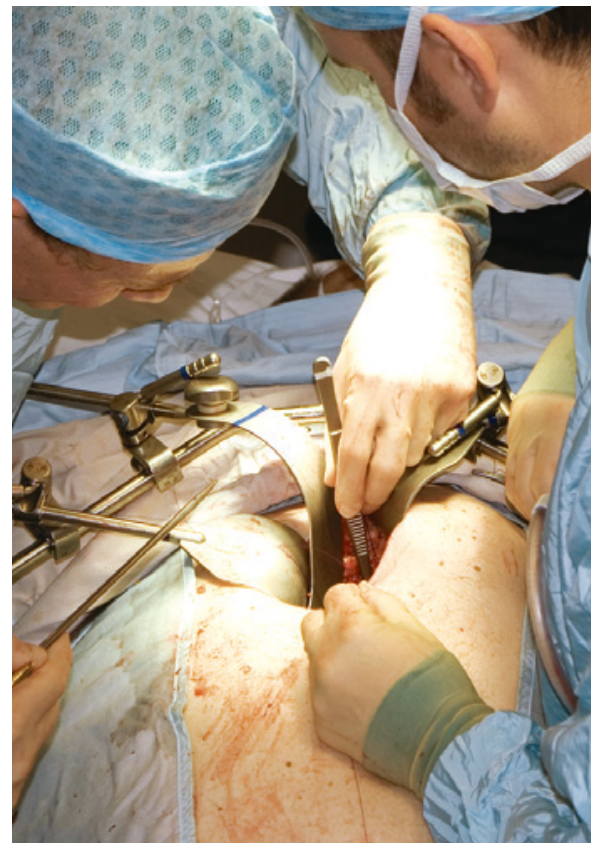

Illustrasjonsfoto Sciencephoto/NTB scanpix 